\title{
PRESTIGIOUS PERCEPTION OF POTATO FARMING: AN OVERVIEW OF THE ECONOMY, SOCIO-CULTURE, AND ITS EXISTENCE
}

\author{
Cahyo Nur Muhammad, Yuli Hariyati* \\ Study Program of Agribusiness, Faculty of Agriculture, University of Jember, Indonesia \\ *corresponding author: yuli.faperta@unej.ac.id
}

\begin{abstract}
Potato farming has been developed by the Tengger Tribe in Ngadisari Village, Sukapura District, Probolinggo Regency. These tribal people cultivate various agricultural commodities, but they feel prestige when farming potatoes. This prestigious perception underlines the research that aims: 1 . To determine the existence of the prestigious perception, 2 . To analyze economically whether potato farming supports the prestigious perception that it can provide higher profits than other plants cultivated on the same land, and 3. Are there socio-cultural reasons for the prestigious perception of potato farming. This study used quantitative methods with 30 respondents selected by purposive sampling. The description method used to know the existence and identify social-cultural factors of the prestigious perception. To prove that economically, analyzed by comparing the potato's farming income with non-potato on the same land. The result showed: 1) $77 \%$ of respondents still feel prestige if they cultivate potatoes, 2) economically, potato farming had a higher income than non-potato farming, and 3) sociocultural factors that support Tengger Tribe feel prestige: a. passed down from generation to generation, $b$. farming complexity challenges, and c. the needs and equality of female workers.
\end{abstract}

Keywords: Income, Potato Farming, Prestigious Perception, Socio-Cultural, Tengger Tribe

\section{INTRODUCTION}

According to the Ministry of Agriculture of the Republic of Indonesia (2019), Probolinggo Regency has the second-largest potato harvest area in East Java Province. The potato development area in this district is on the slopes of Mount Bromo in Sukapura District, which is inhabited by the Tengger Tribe. This tribe has various traditions regarding religions or rituals of local customs. These customs are integrated with various aspects of social, economic, and environmental. One of these aspects is shown in horticultural agricultural activities, even giving rise to commodity priorities or the local term

\begin{abstract}
"Cultivation Class". The priority of this commodity places potatoes as the highest priority, followed by leeks, cabbage, mustard greens, and other commodities. Commodity priority is influenced by hereditary inheritance as a form of community tradition. The priority position as well as the sociocultural and economic influence on potato farming raises a justification for one's welfare/position, even though this farming tends to decrease in land area with many demands that must be met. These demands are high-cost requirements, suitable land, extensive/current knowledge, and a large workforce. A sense of pride and a large income are the basis for
\end{abstract}

CITATION: Muhammad, C., Hariyati, Y., (2021). Prestigious Perception of Potato Farming: an Overview of the Economy, Socio-Culture, and its Existence, Agricultural Socio-Economics Journal, 21(1), 25-32 DOI: 
the perception of potato farming as the main farm of the Tengger tribe.

The depiction of the perception of the prestige of the Tengger tribe towards potato farming is in Ngadisari Village. Socially, this village is a center for cultural development, supported by traditional leaders, cultural routine activities, the majority of Hindus, and a cultural museum. Topographically, Ngadisari Village is located closest to the top of Mount Bromo. The topographical position makes this village tend horticultural agriculture, especially potato farming, which is the highest compared to other villages in Sukapura District. Ngadisari Village also has a different policy from other villages in that land ownership is not allowed to be owned by communities outside the village.

According to Wood (2014), the concept of prestigious perceptions as a psychological constitution originates from various sources. Wasihun, et al. (2014), showed that prestigious perceptions emerged from the policy of increasing potato farming by assessing the level of farmer participation which was influenced by knowledge, capital capacity, and activeness in agricultural programs. Kolech et al. (2015), showed that highquality potato varieties (resistant, tolerant, storage, and processing) would increase the perception of prestige. Mudege, et al. (2016), showed that due to the stereotypical classification of commodity classes by placing OFSP in a higher position as quality farming, it gave rise to a prestigious perception.

The higher the income and the smaller the financing, the prestigious perception of potato farming will increase, and vice versa. Dahal \& Rijal (2019), show that the average potato production is 14.69 tonnes/ha with a low $\mathrm{B} / \mathrm{C}$ ratio of 1.71 due to high labor costs and chemical fertilizers. Siregar (2016), shows that potatoes have the smallest income of 38.07 million/ha and the largest cost with 39.09 million/ha compared to leek and carrots. Taiy, et al. (2017), explained that potato farming is affected by crop rotation which increases income and marketing in the form of cartels.

According to Berger in Wirawan (2012), humans have a dialectical relationship with the socio-cultural world which has a very broad scope of life between humans or the development of life in community activities. Bagheri (2010), shows that the correlation of socio-cultural elements in the form of information sources, participation, and education has a positive effect, while age and experience harm potato farming. Guiriba (2019), shows that knowledge of potato farming is based on the relationships within the community from the community environment, as well as the external environment which influences social, physical, local knowledge and time. Mudege, et al (2017), shows perceptions based on gender differences from the ability to do farming and others.

The purpose of this study, namely (1) To determine the existence of the perception of a prestigious, (2) Analyze the economic is farming potatoes supports the perception of a prestigious which can deliver a higher profit compared to other crops cultivated in the same land and (3) is There any reason social and cultural influence on the perception of prestigious to potato farming.

\section{RESEARCH METHODS}

The research location was in Ngadisari Village, Sukapura District, Probolinggo Regency which was determined deliberately by considering the high yield of horticultural production, especially potatoes, large areas of land, the largest percentage of horticultural farmers in the district, and the center of cultural development. This study used a quantitative method with 30 respondents selected by purposive sampling on Tengger Tribe farmers in Ngadisari Village. Sampling takes into account the number of unknown potato farmers with attention to the precision, trustworthiness, and variability of quantitative research (Roscoe in Sugiyono, 2017).

There are two types of data used, namely primary data and secondary data. Primary data were obtained directly by semi-structured interviews (potato farmers, traditional leaders, and village government) and unstructured participant observation (community behavior, agricultural conditions, and culture). Secondary data is not obtained directly from the field and is used to support primary data, such as village monograph data, traditional books, journals, theses, and the internet (Creswell, 2007). Descriptive analysis was used to determine the existence of perceptions of prestige and socio-cultural factors that led to the emergence of these perceptions of prestige (Priscylio, et al., 2018). The existence of prestigious perceptions is supported by the existence of prestige indicators in the form of appearance, uniqueness, social, hedonic, and quality values (Vigneron \& Johnson, 1999). The scope of socio-cultural factors includes various elements and dimensions of culture, so it needs a description of the factors that drive the perception of prestige (Robin in Wibowo, 2017; Hanafie, 2016).

According to Samadi (2018), farming analysis is to prove economically more prestigious potato 
farming by comparing the income of potato farming with non-potatoes on the same land. The farming analysis is assessed from revenue, financing, profit, and farm efficiency (Abidin \& Puspitasari, 2018).

1. Revenue

$$
\begin{aligned}
& T R=T P \times P y \\
& \mathrm{TR}=\text { Total Revenue }(\text { IDR) } \\
& \mathrm{TP}=\text { Total Production }(\mathrm{Kg}) \\
& \mathrm{Py} \quad=\text { Price of Product }(\mathrm{IDR} / \mathrm{Kg})
\end{aligned}
$$

2. Cost

$$
\begin{aligned}
& T C=F C+V C \\
& \mathrm{TC}=\text { Total Cost (IDR) } \\
& \mathrm{FC}=\text { Fix Cost (IDR) } \\
& \mathrm{VC}=\text { Variable Cost (IDR) }
\end{aligned}
$$

3. Profit

$$
\begin{aligned}
& \left.\begin{array}{l}
\pi=T R-T C \\
\pi=T P . P y-\sum_{i=1}^{n} X_{i} P x_{i}-F C
\end{array}\right\} \text { or } \\
& \pi=\text { Profit (IDR) } \\
& \mathrm{TR}=\text { Total Revenue (IDR) } \\
& \mathrm{TC}=\text { Total Cost (IDR) } \\
& \mathrm{TP}=\text { Total Production }(\mathrm{Kg}) \\
& \text { Py } \quad=\text { Price of Production (IDR) } \\
& \mathrm{X}_{\mathrm{i}}=\text { Factors of Production (satuan faktor) }
\end{aligned}
$$

\section{Prestige Perception on Potato Farming}

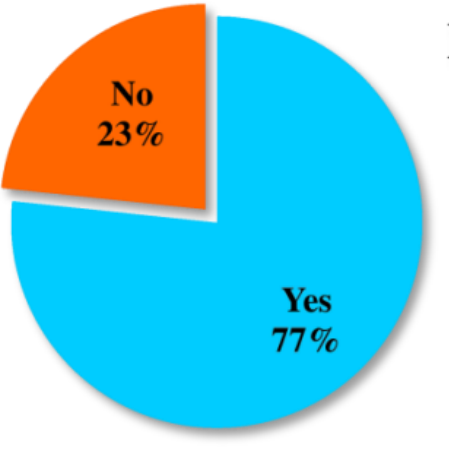

$\mathrm{Px}_{\mathrm{i}}=$ Price of Production Factors (IDR)

$\mathrm{FC}=$ Fix Cost (IDR)

4. Efficiency

$$
R / \text { C ratio }=T R / T C
$$

Table 1. Comparative Farm Yield from Economic Aspects in Ngadisari Village in 2019

\begin{tabular}{lcc}
\hline \multirow{2}{*}{ Indicators } & \multicolumn{2}{c}{ Commodity } \\
\cline { 2 - 3 } & $\mathrm{A}$ & $\mathrm{B}$ \\
\hline Revenue $(\overline{T R})$ & $\overline{T R_{a}}$ & $\overline{T R_{b}}$ \\
Cost $(\overline{T C})$ & $\overline{T C_{a}}$ & $\overline{T C_{b}}$ \\
Profit $(\bar{\pi})$ & $\overline{\pi_{a}}$ & $\overline{\pi_{b}}$ \\
Efficiency $(\overline{R / C})$ & $\overline{R / C_{a}}$ & $\overline{R / C_{b}}$ \\
\hline
\end{tabular}

\section{RESULTS AND DISCUSSION}

The existence of Tengger Tribe Farmers' Prestigious Perceptions of Potato Farming in Ngadisari Village

According to Hayes (2012), prestige is the thought of awe and appreciation. The existence of a prestigious perception of potato farming arises because of the promising acquisition and a noble legacy. The existence of this perception is seen in Figure 1.

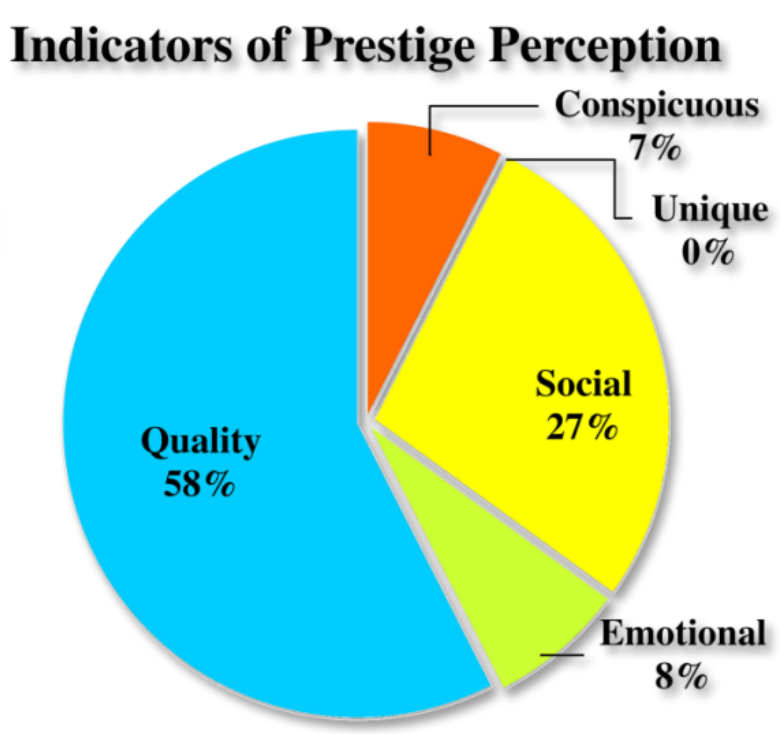

Figure 1. The Existence of The Prestige Perception of Tenggerese Farmers to Potato Farming in Ngadisari Village

Based on Figure 1, there is a tendency of a prestigious perception towards potato farming by $77 \%$. The manifestations of these prestige values include the quality value of $57.5 \%$, the social value of $27.5 \%$, the display value of $7.5 \%$, the hedonic value of $7.5 \%$, and the unique value of $0 \%$. The quality value can be seen from the high demand and product prices so that the income of potato farming is high. The social value between potato farmers is closed due to the high flow of information exchange regarding the development and complexity of farming problems. Social relations appear in routine farmer groups gathering in discussing and running the potato experiment program. Display value is 
seen from the level of welfare supported by the priority of commodities such as potatoes, leeks, cabbage, mustard greens, and other commodities that affect the assessment of one's success. The display value is also seen in the average level of land ownership of the respondents, namely potato farming (1.71 Ha), leek (1.11 $\mathrm{Ha})$, and cabbage (0.67 Ha). The hedonic value appears as an emotional form of pleasure/sensation in itself. The sense of pleasure/sensation arises from the satisfaction of successfully cultivating a potato which is known for its high risk, complicated maintenance, and high cost. There is no unique value because the potato is not a new business or is rarely run, so it is considered common.

The difference of opinion between prestige and non-prestige towards farming arises because of the diversity of characteristics, especially at the level of education and main occupation. Relative opinion on prestige was obtained from respondents with uppermiddle level education and main occupation as farmers. Other characteristics of respondents are based on the farmer's ability in terms of activity level, capital, time, and labor. The point of view will tend to be more prestigious towards farmers who can meet the needs or abilities in potato farming.

\section{Economic Aspects of the Tengger Tribe Farmers' Prestigious Perceptions of Potato Farming in Ngadisari Village}

Economic aspects are very important to be considered in agricultural activities through farming analysis. This analysis includes financing, revenue, and income during the farming process. According to Khusaini (2013), costs are expenses to meet all business needs to provide optimal results in terms of quantity and product quality. The minimum cost requirement will increase the prestige value of farming activities, but in some conditions the higher the cost will increase the prestige value if it is directly proportional to the acquisition/benefit value (Kirmani \& Baumgartner, 2000). Revenue is the product of the quantity of production and the price of the product. Income is the result of farming after deducting the cost requirements which are influenced by the level of production, price, land area, use/need for input, and other things beyond the farmer's control. The relationship between revenue and income is directly proportional to the perception of prestige, namely the higher the farm acceptance and income, the higher the prestigious perception of farming (Soekartawi et al., 2017).

There are various other horticultural farms besides potatoes that are run by Tengger Tribe farmers such as leeks and cabbage. The amount of input and capital needs, as well as the level of income of each farm, will raise a prestigious perception. A prestigious perception will appear in farms that provide high income and minimal costs (Samadi, 2018). The results showed that the Tengger tribe farmers' perception of prestige tended to be more towards potato farming than non-potato commodities because of the high income from the large productivity and stable product prices. Easy market access conditions and long shelf life also support the marketing of potato farming. The availability of inputs is also widely available to meet the very large input needs of potato farming compared to other farms. The support can overcome various difficulties or obstacles that pose a risk in potato farming which has a high level of complexity. The following are the results of the economic aspects of the potato and non-potato farming in Ngadisari Village, which was carried out by 30 potato farmer respondents conducted during 2018 in table 2 .

Table 2. Comparison of Average Farming Commodities per Hectare on Tenggerese Farmers in Ngadisari Village in 2019

\begin{tabular}{llrrrrrr}
\hline No & \multicolumn{1}{c}{ Indicators } & & \multicolumn{1}{c}{ Potato } & & \multicolumn{1}{c}{ Leek } & & \multicolumn{1}{c}{ Cabbage } \\
\hline 1 & Costs & & & & & & \\
& $>$ Fix Costs & IDR & $231,446.22$ & IDR & $232,781.99$ & IDR & $299,713.93$ \\
& $>$ Variable Costs & IDR & $83,636,605.14$ & IDR & $45,786,670.97$ & IDR & $22,764,917.41$ \\
& $>$ Total Costs & IDR & $83,868,051.36$ & IDR & $46,019,452.95$ & IDR & $23,109,646.27$ \\
2 & Revenue & IDR & $137,008,797.65$ & IDR & $90,641,025.64$ & IDR & $36,322,388.06$ \\
3 & Profit & IDR & $53,140,746.30$ & IDR & $44,621,572.69$ & IDR & $13,212,741.79$ \\
4 & R/C Ratio & & 1.634 & & 1.970 & & 1.572 \\
\hline
\end{tabular}

Source: Primary Data, 2020 (processed) 
Based on table 2, it shows the comparison per commodity in the aspects of financing, income, profit, and farming efficiency. The comparison of leek commodities used is the monoculture cropping pattern as a result of the intercropping pattern data conversion. Based on the aspect of financing the most prestigious cabbage commodity with the smallest cost of IDR 23,109,646.27. Minimum costs indicate lower capital requirements, while potatoes have the highest financing, making only farmers with the strong capital capacity to cultivate them. This condition can also provide a different assessment when the farming community states that the higher the funding will indicate the ability to do business, both in capital, knowledge, and courage to take risks.

Based on the revenue aspect of potato farming, the largest value was IDR 137,008,797.65. Higher acceptance will motivate farmers to run farming. Based on the value of profit is directly proportional to the value of acceptance, namely the higher the profit will increase the perception of prestige. The biggest profit as well as the most prestigious is potato farming amounting to IDR 53,140,746.30. Based on the $\mathrm{R} / \mathrm{C}$ ratio or efficiency, the greater the value of the ratio will increase the perception of prestige. Based on the value of the $\mathrm{R} / \mathrm{C}$ ratio, the monoculture pattern of leek farming is the most efficient at 1.97 , which means that every IDR 1.00 of costs incurred gives an income of IDR 1.97.

Socio-Cultural Aspects of the Prestigious Perceptions of Tengger Tribe Farmers on Potato Farming in Ngadisari Village

Socio-cultural aspects are closely related to human life. Some elements are formed from and for the continuation of human life. Culture is defined as an order of values in society. The following are the socio-cultural reasons for the perception of the prestige of potato farming.

\section{Factors of Socio-Cultural Aspects}

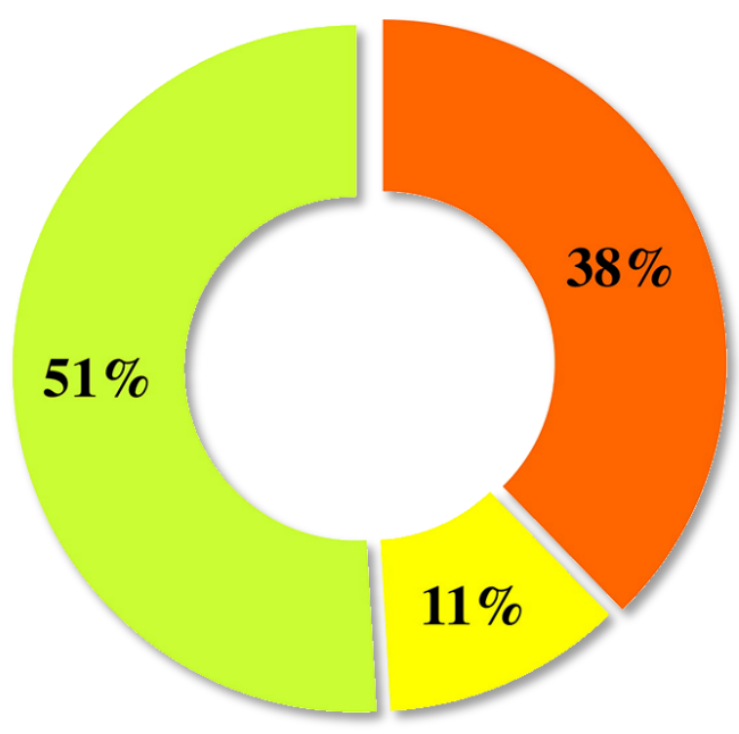

\section{Pass down from generation to generation}

Farming complexity challenges

Figure 2. Socio-Cultural Reasons for the Prestigious Perceptions of Tengger Tribe Farmers on Potato Farming in Ngadisari Village

Based on Figure 2, the influence of the sociocultural aspects is because the people of Ngadisari Village still highly uphold social life, and still maintain a noble heritage in the form of culture. This condition is not a strange thing when various activities in people's lives are influenced by sociocultural aspects, including the development of prestigious perceptions of potato farming. The reasons for the emergence of perceptions of prestige from the largest to the smallest percentage were the need and equality of female workers at $51 \%$, inheritance from generation to generation at $38 \%$, and the challenges of farming complexity by $11 \%$.

The inheritance from generation to generation is marked by potato farming as a tradition/culture. This tradition makes the community try to cultivate potatoes even though it is only on a small portion of their land and the crop rotation tends to not work. This farming heritage is also a form of gratitude, respect, and devotion to Sang Hyang Widhi and his 
ancestors. There are also traditional ceremonies such as Kasada and leliwet as ceremonies in commemoration of the story of Rara Anteng-Jaka Seger and post-harvest. Most of the land ownership is inherited land because the Ngadisari Village policy requires that land can only be owned by the village's original community.

Farming complexity challenges because it provides emotional sensations. The sensation is in the form of pride and relief after being able to complete various stages, challenges, and obstacles in potato farming. Potato farming requires a lot of labor, large capital, high pest attack, and up-to-date knowledge. This complexity causes the farming community to feel challenged in part, even though some other farmers feel it is the pressure that even reduces motivation.

The need and equality of female labor is the biggest reason because potato farming consists of various stages, mainly in the needs of land cultivation and routine maintenance. The average land area for potato farmers is the largest compared to other farms, which is about 1.71 hectares from 30 respondents. The area of land is classified at the level of wide land, so it is not possible to do it only by family workers as well as male workers. The female workers of the Tengger tribe are also known as strong, independent, and intelligent women because they have started to dive and have been taught about potato farming since they were small and generally have a minimum high school education. Equality can be seen from participating in decision making (using inputs from the types of seeds, fertilizers, and pesticides) and engaging in strenuous activities (cultivating land, transporting inputs/harvesting, and routine maintenance in the form of spraying with diesel).

\section{CONCLUSION}

The results of the assessment show that there is a perception of the Tengger tribe farmers' prestige towards potato farming in Ngadisari Village by 77\%. A prestigious manifestation of the quality value of potatoes as high income, the main commodity, and hereditary farming. The economic aspect shows the perception of prestige in terms of the highest profit, namely potato farming of IDR $53,140,746.30$, but it is also the farm with the highest financing of IDR 83,868,051.36 compared to the non-potato farming of the Tengger tribe farmers. The socio-cultural aspect affects the perception of prestige for 3 main reasons, namely inheritance from generation to generation, the challenges of the complexity of farming, and the need for female labor.

Further studies with a qualitative approach concern the prestigious perceptions of Tengger Tribe farmers in other Tengger Tribe distribution areas such as in Lumajang, Malang, or Pasuruan districts, so that they can compare with previous research results and produce in-depth data. Potato farming has the highest yield, but this is not the case with the $\mathrm{R} / \mathrm{C}$ ratio. It is necessary to increase the efficiency of care through biological control in minimizing drug use and high labor requirements.

\section{REFERENCES}

Abidin, Z., \& Puspitasari, H. P. (2018). Mina Bisnis Ikan Cupang: Teori dan Aplikasi. Malang: Universitas Brawijaya Press.

Bagheri, A. (2010). Potato Farmers' Perceptions of Sustainable Agriculture: The Case of Ardabil Province of Iran. In Procedia - Social and Behavioral Sciences. https://doi.org/10.1016/j.sbspro.2010.07.399

Creswell, J. W. (2007). Qualitative Inquiry and Research Design: Choosing Among Five Approaches (2nd ed.). California: Sage. Retrieved from https://books.google.co.id/books?id=DetLkgQ eTJgC\&printsec $=$ frontcover $\mathrm{v}=$ onepage $\& \mathrm{q} \& \mathrm{f}$ $=$ true

Dahal, B. R., \& Rijal, S. (2019). Production Economics and Determinants of Potato Production in Nuwakot, Nepal. International Journal of Applied Sciences and Biotechnology, 7(1), 62-68. https://doi.org/10.3126/ijasbt.v7i1.23304

Guiriba, G. O. (2019). Documentation of Indigenous Knowledge on Production and Post-Harvest Management of Sweet Potato in The Bico Region, Philippines. Asian Rural Studies, 3(1), 93-108.

Hanafie, S. R. D. R. (2016). Ilmu Sosial Budaya Dasar. (F. Sigit, Ed.). Yogyakarta: Andi.

Hayes, J. C. (2012). The Unexpected Evolution of Language: Discover the Surprising Etymology of Everyday Words. London: Simon and Schuster.

Kementerian Pertanian Republik Indonesia. (2019). Luas Panen Kentang. Retrieved November 21, 2019, from https://aplikasi2.pertanian.go.id/bdsp/id/lokasi

Khusaini, M. (2013). Ekonomi Mikro: Dasar-dasar Teori. Malang: Universitas Brawijaya Press. 
Kirmani, A., \& Baumgartner, H. (2000). Reference Points Used in Quality and Value Judgements. Marketing Letters, 11(4), 299-310. https://oi.org/10.1023/A:1008129011202

Kolech, S. A., Halseth, D., De Jong, W., Perry, K., Wolfe, D., Tiruneh, F. M., \& Schulz, S. (2015). Potato Variety Diversity, Determinants, and Implications for Potato Breeding Strategy in Ethiopia. American Journal of Potato Research, 92(5), 551-566. https://doi.org/10.1007/s12230-015-9467-3

Mudege, N. N., Chevo, T., Nyekanyeka, T., Kapalasa, E., \& Demo, P. (2016). Gender Norms and Access to Extension Services and Training among Potato Farmers in Dedza and Ntcheu in Malawi. Journal of Agricultural Education and Extension, 22(3), 291-305. https://doi.org/10.1080/1389224X.2015.1038 282

Priscylio, G., Rochintaniawati, D., \& Anwar, S. (2018). Needs of Integrated Science Textbook for Junior High School Based on Learning Style (Descriptive Research). International Conference on Mathematics and Science Education (ICMScE), 3(1), 396-401.

Samadi, B. (2018). Sukses Budidaya Kentang di Dataran Tinggi dan Dataran Medium. Jakarta: Pustaka Kemang.

Siregar, A. (2016). Analisis Kelayakan dan Resiko Usahatani Bawang Prei Dibandingkan dengan Sayuran Lainnya (Studi Kasus: Desa Merdeka, Kecamatan Merdeka, Kabupaten Karo Provinsi Sumatera Utara). Universitas Sumatera Utara, 1(1), 1-13.

Soekartawi, Soeharjo, A., Dillon, J. L., \& Hardaker, J. B. (2017). Ilmu Usahatani dan Penelitian untuk Pengembangan Petani Kecil (p. 253). Jakarta: Universitas Indonesia Press.
Sugiyono. (2017). Metode Penelitian Kuantitatif, Kualitatif, dan Kombinasi (Mixed Methods). Bandung: Alfabeta.

Taiy, R. J., Onyango, C., Nkurumwa, A., \& Ngetich, K. (2017). Socio-economic Characteristics of Smallholder Potato Farmers in Mauche Ward of Nakuru County, Kenya. Universal Journal of Agricultural Research, 5(5), 257-266. https://doi.org/10.13189/ujar.2017.050502

Vigneron, F., \& Johnson, L. W. (1999). A Review and a Conceptual Framework of PrestigeSeeking Consumer Behavior. Academy of Marketing Science Review, 3(1), 1-15.

Wasihun, B. N., Kwarteng, J. A., \& Okorley, E. L. (2014). Farmers' Perception of Their Level of Participation in Extension in Ethiopia: Policy Implications. Journal of Agricultural Extension and Rural Development, 6(2), 80 86. https://doi.org/10.5897/jaerd2013.0516

Wibowo. (2017). Perilaku dalam Organisasi. Depok: PT Rajagrafindo Persada.

Wirawan. (2012). Teori-Teori Sosial dalam Tiga Paradigma: Fakta Sosial, Definisi Sosial, dan Perilaku Sosial. Sleman: Kencana.

Wood, S. (2014). Nations, National Identity, and Prestige. National Identities, 16(2), 99-115. https://doi.org/10.1080/14608944.2014.89731 5 
This page is intentionally left blank 